
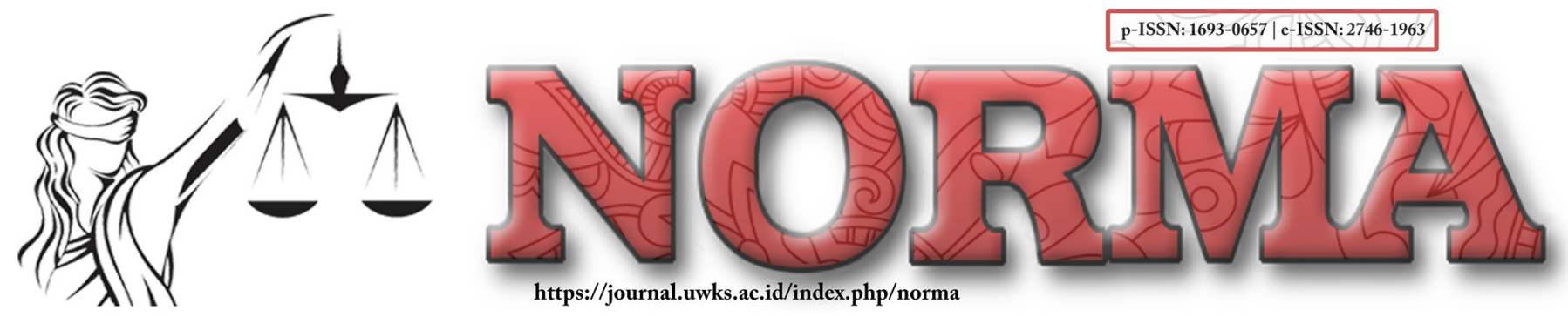

\title{
Rejection of Accident Insurance Claims by Insurance Companies
}

\author{
Berto Tegar Samudera \\ Legal Observer \\ e-Mail: bts168@mhs.uwks.ac.id
}

\begin{abstract}
:
Insurance is a form of compensation for the occurrence of uncertain risks and the delegation of responsibility to bear those risks. The event of this risk is uncertain because it depends on uncertainty. The transfer of risk is carried out by making an insurance agreement or insurance agreement. The first party is usually referred to as the insured. The second is the party willing to accept the risk of the first party by accepting a payment called a premium. Risk takers are often referred to as insurance companies. The research method used in this study uses a legal approach research method (statute approach) and a conceptual approach (conceptual approach). Based on the results of this study, the researcher states that the basis or cause of the rejection of an insurance agreement is because the insurance agreement is a conditional agreement, where the insurer only bears the loss suffered by the insured party following the terms of the event that resulted in the loss to the insured as agreed, by the parties in the insurance agreement. Or the insured party does not carry out its obligations to pay premiums to the insurer. The legal remedy that the insured party can take if the insurer rejects the claim is to file a lawsuit at the local District Court, as regulated in Article 23 of Law no. 8 of 1999. It can be completed through the BMAI institution.
\end{abstract}

Keywords: Insurance; Claim; Dispute Resolution.

Article's History:

Received:

June 14, 2021;

Peer-Reviewed: June 21, 2021;

Accepted:

July 15, 2021;

Published:

July 30, 2021.

DOI:

10.30742/nlj.v18i2.1585

\section{INTRODUCTION}

In their nature as social beings and individual beings, humans always try to fulfill all their needs. To meet the needs of life, humans always have to face unexpected situations. This proves that humans will always be faced with the possibility of something happening in the course of their lives. This event can harm him, his family, and the people who care about him, such as accidents and others. In an extreme form or event, a state of uncertain probability that gives risk. Institutions or organizations that can accept other people's risks are insurance organizations or insurance companies. Insurance companies in their line of business openly try to offer/provide protection and hope for the future to every person or group living in the community or other organization regarding the ability to bear additional losses due to an uncertain event. 
Insurance or compensation always includes the existence of a risk and the delegation of responsibility to bear that risk. The occurrence of this risk is uncertain because it depends on uncertainty. The other party who accepts responsibility and opposes the other party to give this responsibility is obliged to pay a sum of money to the beneficiary. In this regard, Abdulkadir Muhammad stated, the risks that can be insured are:

a. As far as value in money;

b. Must be a pure risk, meaning that it only has the opportunity to cause harm;

c. Losses arising as a result of the occurrence of an event that is not fixed or definite;

d. The insured must have an insurance interest;

e. Not prohibited by statutory provisions and does not conflict with and violate public order. $^{1}$

The transfer of these risks is carried out by making an insurance agreement or an insurance agreement. The risk faced or accepted by one party by making an agreement, which is delegated to another party, namely the guarantor. There is an insurance agreement as mentioned in it; there are two parties. The insured party in question is the party that should bear the risks it faces but prefers to transfer the threats it faces to another party. The second is the party who is able and willing to accept and bear the risk experienced by the insured party through receiving payment of an agreed amount of money from the insured party, which is commonly referred to as a premium. Risk takers are often referred to as insurance companies.

Insurance companies in providing insurance claims are also not easy enough to make insurance claims. This is because so many factors can affect the difficulty of an insurance claim, the problem of the insurance claim process, and the potential for the proposed insurance claim to be rejected by the insurance company. Furthermore, insurance companies will discuss the causes of rejection of insurance claims by insurance companies when submitting insurance claims based on the insurance agreement. ${ }^{2}$

\section{RESEARCH METHOD}

This research is normative legal research with a statutory approach.

\section{DISCUSSION}

Insurance or coverage agreements are regulated explicitly in the Commercial Code. Therefore, this agreement is categorized as an agreement that is special and governed by special provisions. However, taking into account Article 1 of the Civil Code, the general conditions of the agreement in the Civil Code are as lex general or special rules that must not be violated or omitted as long as they have not explicitly

${ }^{1}$ M. Abdul kadir, Hukum Acara Perdata Indonesia (Bandung: Citra Aditya Bakti, 1990), 119.

${ }^{2}$ Fani Martiawan Kumara Putra, "Characteristic of Preliminary Rights For Insured in Getting Repayment of Losses on Bankrupt Insurance Companies," Perspektif 22, no. 2 (2017): 180-89. 
been regulated in the provisions of the Criminal Code. The regulatory system used in the KUHD does not appear to be systematic enough due to improper layout and presentation, resulting in inappropriate locations. Therefore, special skills are needed to be able to carry out learning well. ${ }^{3}$

Article 246 of the KUHD determines that insurance is an agreement whereby the insurer has an obligation to the insured, by collecting premiums, to compensate for the loss, damage, or loss of income that may be suffered by the insured as a result of the occurrence of an unknown event or which is feared to occur.

The limit mentioned above by Emmy Pangaribuan was further developed as follows: ${ }^{4}$ Insurance is an agreement between the insurer and the insured, in which the insurer will get a premium from the insured to compensate for losses that are not expected by the insured because the loss occurs due to loss or lack of profit that may be suffered by the insured in the event of an unexpected event.

From the limitations mentioned above, Emmy Pangaribuan further explained that an insurance or insurance contract has the following characteristics: ${ }^{5}$

1. Insurance is a compensation contract (shcadeverzekering or indemnities contract). Where the insurer states the ability to replace the claim because the insured suffers a loss and what is replaced by the insurer is the same as the actual damage sustained by the insured (principle of indemnity);

2. An insurance or coverage agreement is a conditional agreement. The insurer's obligation to compensate for losses is only fulfilled if an event occurs where the implementation of insurance occurs;

3. An insurance agreement or coverage is a reciprocal agreement. The insurer's liability for compensation as the insurer is expected to be equivalent to the insured's obligation to pay premiums;

4. Losses are unspecified events in which liability is involved.

Article 246 of Wetboek van Koophandel, contain 3 (three) main characteristics of the insurance agreement, which is stated as follows: ${ }^{6}$

1. Insurance is an agreement or indemnity agreement or an indemnity contract that is remembered by one party (the insurer) against another party (the policyholder or the insured) to repay the loss; usually the loss it may suffer;

2. Insurance can be said as a conditional agreement; in other words, the insurer bears the compensation suffered by the insured in an unpredictable situation;

3. Insurance is said to be a reciprocal agreement. This means the insurer has a guarantee with conditions given to the insured for the loss suffered by the insured.

\footnotetext{
${ }^{3}$ Sri Rejeki Hartono, Hukum Asuransi Dan Perusahaan Asuransi (Jakarta: Sinar Grafika, 2001), 90.

${ }^{4}$ Emmy Pangaribuan, Hukum Pertanggungan Dan Perkembangannya (Yogyakarta, 1990), 22.

${ }^{5}$ Ibid.

${ }^{6}$ P.L. Wery, Hoofzaken van Het Verzekeringsrecht (Deventer: Kluwer B.V, 1984), 7.
} 
Furthermore, P.L. Wery, still in the same book, argues that 2 (two) other characteristics of an insurance agreement, although not regulated in the same article (namely in 246 KUHD) a different theme, namely the provisions contained in article 257 and 258 KUHD, are as follows: ${ }^{7}$

1. Insurance is a consensual agreement that can arise after a contract is made, namely a contract without a form;

2. Insurance has a unique nature: trust, mutual trust between the parties who determine the agreement itself.

The provisions in Article 246 of the KUHD, which regulates the limits of insurance contracts, are the main elements of the regulatory system for insurance contracts. The article regulates a legal relationship by using certain conditions that must be fulfilled in an agreement to be referred to as an insurance contract. The unique nature stipulated in Article 246 of the KUHD is used as the basis of an insurance contract, complementing other important principles as regulated further in the KUHD. The principles referred to above are additional principles for insurance contracts held in articles 250, 251, 253, 257, 258, 266, etc., from KUHD.

Chapter $X$ deals with several types of insurance in the same book, including fire risk coverage for unharvested agricultural products and life insurance. The second book is regulated about insurance against the dangers of the sea and the dangers of slavery in Chapter IX and Chapter $X$ concerning insurance against the risks in transportation on land, rivers, and inland waters.

Insurance contracts have unique properties and characteristics compared to other contracts and need to be studied and studied more deeply to understand them fully. The main difference between insurance contracts and other agreements lies in the performance of the service. In general, the parties' achievements in other agreements can be carried out together immediately and simultaneously. Thus, creditors and debtors can simultaneously do other work. That way, it can be immediately known who has succeeded and who has not so that the parties' position can be learned, for example, in contracts of sale, lease, transportation, etc. However, in contrast to insurance contracts whose primary purpose is an agreement to provide protection and compensation, the mechanism is not as simple as other agreements. ${ }^{8}$

There is a time gap in the insurance agreement to carry out the performance between the I/Insurer and the II/Insured party's achievements. The hole in question occurs because the insurer's achievements still have to depend on a "certain uncertain event/condition," which is also a requirement in the insurance agreement, namely an economic loss suffered by the insured caused by the occurrence of the uncertain event Therefore, even though the performance of the second party/insured has been perfectly

${ }^{7}$ Ibid., 8.

${ }^{8}$ Fani Martiawan Kumara Putra, "Urgency of Notary Engagement as a Limitation on the Freedom of Contracts on the Pre-Project Selling Events," Perspektif 24, no. 2 (2019): 101-17. 
implemented, the first party/insurer/insurance company cannot immediately carry out its performance perfectly if the event agreed upon between the parties does not/ has not occurred. So one achievement cannot be directly and simultaneously carried out reciprocally with the other party's investment because it is still dependent on an uncertain event. Due to its unique nature, the insurance agreement requires a more thorough study by paying attention to certain interrelated moments that do not always occur together. The first momentum is when the insurance agreement occurs and is valid, while the second momentum is when the insurance agreement is implemented. These two momentums have a reasonably long-time gap of up to one year following the termination of the contract (for example, in fire insurance). Even the events that were agreed upon did not happen at all. (In this case, the insured does not suffer a loss at all, so the insurer's tangible achievement of paying compensation does not need to occur. $^{9}$

These circumstances typically give color and character to insurance agreements, so this agreement requires a different study and approach to other types of payrolls. In addition, the insurance agreement, even though in absolute terms it only concerns the parties, can ideally involve the interests of the broader community since the object of the insurance agreement concerned has an essential meaning for the wider environment. So basically, an insurance contract is a contract with precise characteristics that will provide its advantages compared to other agreements.

Article 255 of the Commercial Code states that as proof of the existence of an insurance agreement is the existence of a policy. Still, according to Article 257 of the Commercial Code, an insurance contract is evidence, but without an insurance policy, an insurance contract has been made when the insurance policy is closed. Moreover, the insurance agreement since it was made has the right to bind both parties as a mandatory law according to Article 1338 paragraph 1 of the Civil Code, that all valid agreements apply as law for those who carry it out, while Article 1338 paragraph two of the Civil Code states that the contract cannot be terminated without the agreement of both parties or for reasons determined by law article 1266 of the Civil Code. The provisions of article 1266 of the Civil Code are described in advance as follows:

The void condition is considered to always exist in a reciprocal agreement, as long as one of the parties does not carry out its obligations. The agreement is not null and void in such a case, but the judge must request the cancellation. This request must also be fulfilled, even if the non-performance condition of cancellation is provided for in the agreement. For example, suppose the terms of cancellation are not stated in the agreement. In that case, the judge may, on a case-by-case basis, be free, at the request of the defendant, for a specific time to continue to fulfill his obligations, but this period will not be exceeded by a month.

\footnotetext{
9 Wery, Hoofzaken van Het Verzekeringsrecht, 92.
} 
According to article 1266 of the Civil Code, there are controversial issues between these verses if you look closely. Article 1266 paragraph 1 of the Civil Code states that the terms of termination always exist in a reciprocal agreement if one party fails to fulfill its obligations or becomes bankrupt. Thus, according to the provisions of article 1 , a default is a condition of the void. However, in article 1266, paragraph 2 of the Civil Code, the agreement is not automatically null and void by law if there is a default. Still, it must be requested for cancellation by the judge. As a result, the provisions of Article 1266 of the Civil Code are, of course, controversial.

Article 1266 of the Civil Code concerning the conditions for revocation relating to prohibitions in an agreement are revoked unilaterally unless agreed otherwise by both parties or for specific reasons. Article 1338 paragraph 2 of the Civil Code. Unilateral termination of the contract can be carried out because the Power Purchase Agreement violates Article 1266 of the Civil Code.

To see the problem of applying clauses other than those regulated in Article 1266 of the Civil Code, you must consider each case on a case-by-case basis. For example, in cases involving commercial agents and consumers, there is a need for legal protection for consumers against unilateral actions by commercial agents without a court decision. However, there must be legal certainty for the parties to respect their rights and obligations in the case between a business entity and a business entity.

Insurable Interest is an absolute requirement to make an insurance contract. If there is no insurable interest, the insurance contract becomes invalid or void. As stated by Chris Parsons, David Green, and Mike Mead (1995), Insurable Interest is "Legal insurance rights arising from the economic relationship between the insured and the insured subject recognized by law." Therefore, it is a legal right to take insurance coverage for the relationship between the insured and financial purposes. a person can be interested in in the insured object if that person suffer a loss due to the loss or damage to the insured entity. ${ }^{10}$

The necessity of insurable interest Insurance contracts are intended to have an insurable interest to prevent insurance from becoming a game. But unfortunately, bad things happened to the object in question. ${ }^{11}$ Concerning the responsibilities of business actors, in this case, the insurer is regulated in the Law on Insurance Business, Number 40 of 2014. In other words, Article 31 of the Insurance Law stipulates as follows:

1. Insurance business actors, whether agents, brokers, or business entities, are expected to apply all expertise, prudence, and accuracy when providing services or dealing with policy owners, insured persons, or participants;

2. Insurance business actors, both agents, brokers, and business entities offer 2 (two) conventional and sharia insurance products;

${ }^{10}$ Kun Wahyu Wardana, Hukum Asuransi-Proteksi Kecelakaan Transportasi (Bandung: Mandar Maju, 2009), 31.

${ }^{11}$ Joko Trilaksono, Perlindungan Hukum Pemegang Polis Asuransi Terhadap Kendaraan Bermotor Dalam Angkutan Penyeberangan, n.d., 30. 
3. Business actors in the insurance sector, whether agents, brokers, or business entities, need to process claims and complaints through a system that is fast, accessible, and impartial;

4. Insurers, sharia insurers, reinsurers, and sharia reinsurers take or must take steps that can delay claims or payments, resulting in delays in claims or expenses;

5. As referred to in paragraph (3), the new rules for handling claims and complaints are processed quickly, easily accessible, and impartially regulated in the provisions of the Financial Services Organization Rules.

Of course, the number of claims from insurance consumers does not mean that insurance companies routinely violate consumer rights. Insurance consumers are also vulnerable to fraud by presenting inaccurate and complete facts (misrepresentation), which in principle can influence the insurance company's decision to accept or not accept the risk proposed by the insured or determine the amount of premium. You need to know that the dispute needs to occur, and the trigger can come from the insurer or the insured for effective legal documents and dispute resolution mechanisms. Law Number 8 of 1999 concerning Consumer Protection is a legal instrument that can handle and resolve disputes. ${ }^{12}$

Sri Rejeki provides a method on how to detect insurable interests using the following metrics: ${ }^{13}$

1. The extent to which the insured's a relationship with the subject/object of the insurance policy until the occurrence of the agreed event;

2. Events that have occurred did they result in loss or not.

There is an application of this insurable Interest that can be different by looking at the type of insurance. ${ }^{14}$

1. Life Assurance. Everyone has an insurable interest that is not limited to themselves, and in theory, anyone can insure for any amount of coverage. However, a person's ability to pay premiums will restrict the amount of coverage desired. In addition to people who have an insurable interest in you, someone who lives in a husband-wife relationship may also have an insurable interest as your life partner. A husband can guarantee his wife;

2. Property insurance. Insurable interest Property insurance is relatively easy to determine using the property approach. Property owners will inevitably suffer losses if their property is damaged or destroyed. Associated with part or joint owners, partial ownership of an asset can guarantee the exclusive right. This does not mean that the insurance company will also be fully compensated for loss or damage to property. The amount of compensation received is always adjusted to the percentage of damaged joint property. For example, the Trustee

${ }^{12}$ Ibid., 31 .

${ }^{13}$ Hartono, Hukum Asuransi Dan Perusahaan Asuransi, 100-101.

${ }^{14}$ Wardana, Hukum Asuransi-Proteksi Kecelakaan Transportasi, 34. 
may insure the entire amount of the property entrusted to him even if he was only partially interested. In the event of a request, the excess of specific interests must be transferred to other parties who have the same interests;

3. Hak Tanggungan Hak Tanggungan are prevalent in home buying transactions. Hak Tanggungan is a written delivery of real estate law as collateral for paying a debt provided that the delivery is canceled at the time of payment. Both parties have an insurance interest;

4. Executor $\mathcal{E}$ Trustee. Executors and Trustees establish in writing the title of property as security for the payment of a debt provided that the surrender is canceled at the time of payment. For stakeholders, they have an insurable interest in the entrusted property.

5. Bailees. Bailee is the person who is responsible for other people's belongings given to him, whether loaded or not. Pawnshop owners, laundry owners, and workshop owners are examples of items provided by Bailee owners (pawnshops, laundry items, repair shops), each of which has its responsibilities;

6. Agents. The principal or employer has an insurable interest in his agent and can insure on his behalf.

7. Marine insurance. British law provides actual limits on the interests that can be insured in Article 5 of the Marine Insurance Act of 1906. This provision states that in the interests of the insured, the insured enjoys the security of his property and is liable for losses if the property is destroyed or broken.

Violation of the principle of honesty does not necessarily become the fault of the insured. For example, if the insured does not know that he is sick, then the insurer is obliged to check the insured's health condition. Thus, if there are future health problems that the insured does not meet the policy's requirements, it can be avoided. In addition, the insured provides false or unfaithful information because the insured's fraud can be known. Therefore, in addition to rejection due to a violation of the principle of good faith or the provision of false information, denial of a claim is also caused by noncompliance with the insurance policy provisions. ${ }^{15}$ The insured or policyholder must avoid claim rejection; for various reasons, claims can be rejected. ${ }^{16}$

Regarding insurance claims, it is regulated in several regulations, namely Article 23 Paragraph (1) Government Regulation of the Republic of Indonesia Number 1992 as amended by Government Regulation Number 39 of 2008 concerning the second amendment to Government Regulation Number 73 of 1992 as follows: “Insurers or reinsurers prohibited from taking actions that can cause delays in settlement of claims,

${ }^{15}$ Aditama Setya Prakoso, "Polis Asuransi Jiwa Sebagai Alat Bukti Penuntutan Klaim Dalam Perjanjian Asuransi Jiwa (Studi Di PT Asuransi Jiwasraya Semarang Timur)," Diponegoro Law Journal Vol. 5 (2016): 9.

${ }^{16}$ Hilda Yunita Sabrie, "Pembayaran Klaim Asuransi Jiwa Akibat Tertanggung Bunuh Diri," Jurnal Yuridika Vol. 26 No (2011): 42. 
or not taking steps that can result in delays in settlement and payment. Considering the description above, it can be explained that in an insurance contract, the rights and obligations of the parties that arise are called redemption rights and responsibilities. The existence of this defect gives the injured party the right to file a lawsuit based on the fault to the District Court or resolve it without litigation, primarily through BMAI or BPSK.

\section{CLOSING}

\section{Conclusion}

The basis or cause of the rejection of an insurance agreement is because the insurance agreement is a conditional agreement, where the insurer only bears the loss suffered by the insured party following the conditions of the event that resulted in the loss to the insured as agreed by the parties in the insurance agreement. Or the insured party does not carry out its obligations to pay premiums to the insurer.

\section{Recommendation}

Legal experts and the government should form rules that specifically regulate insurance agreements and proper protection for both the insurer and the insured.

\section{REFERENCES}

Aditama Setya Prakoso. "Polis Asuransi Jiwa Sebagai Alat Bukti Penuntutan Klaim Dalam Perjanjian Asuransi Jiwa (Studi Di PT Asuransi Jiwasraya Semarang Timur)." Diponegoro Law Journal Vol. 5 (2016).

Emmy Pangaribuan Simanjuntak. Hukum Pertanggungan Dan Perkembangannya. Yogyakarta, 1990.

Hartono, Sri Rejeki. Hukum Asuransi Dan Perusahaan Asuransi. Jakarta: Sinar Grafika, 2001.

Hilda Yunita Sabrie. "Pembayaran Klaim Asuransi Jiwa Akibat Tertanggung Bunuh Diri." Jurnal Yuridika Vol. 26 No (2011).

Joko Trilaksono. Perlindungan Hukum Pemegang Polis Asuransi Terhadap Kendaraan Bermotor Dalam Angkutan Penyeberangan, n.d.

M. Abdul kadir. Hukum Acara Perdata Indonesia. Bandung: Citra Aditya Bakti, 1990.

Putra, Fani Martiawan Kumara. "Characteristic of Preliminary Rights For Insured in Getting Repayment of Losses on Bankrupt Insurance Companies." Perspektif 22, no. 2 (2017): 180-89.

- - - "Urgency of Notary Engagement as a Limitation on the Freedom of Contracts on the Pre-Project Selling Events." Perspektif 24, no. 2 (2019): 101-17.

Wardana, Kun Wahyu. Hukum Asuransi-Proteksi Kecelakaan Transportasi. Bandung: Mandar Maju, 2009.

Wery, P.L. Hoofzaken van Het Verzekeringsrecht. Deventer: Kluwer B.V, 1984. 